\title{
Mapping of Angular Leaf Spot Disease Hotspot Areas in Western Kenya Towards Its Management
}

\author{
Robert Kiptabut Leitich" ${ }^{1,}$, W. Arinaitwe ${ }^{3}$, B. Mukoye ${ }^{1}$, D. O. Omayio ${ }^{1}$, A. K. Osogo ${ }^{2}$, H. K. Were ${ }^{1}$, \\ J. W. Muthomi ${ }^{4}$, R. M. Otsyula ${ }^{5}$, M. M. Abang $^{6}$ \\ ${ }^{1}$ Biological Sciences Department, Faculty of Science, Masinde Muliro University of Science and Technology (MMUST), Kakamega, Kenya \\ ${ }^{2}$ Biological Sciences Department, Faculty of Science, Kibabii University, Bungoma, Kenya \\ ${ }^{3}$ International Centre for Tropical Agriculture (CIAT), Kawanda, Uganda \\ ${ }^{4}$ Department of Plant Science and Crop Protection, Faculty of Agriculture, University of Nairobi (UON), Nairobi, Kenya \\ ${ }^{5}$ Kenya Agricultural and Livestock Research Organisation (KALRO), Kakamega, Kenya \\ ${ }^{6}$ Food and Agriculture Organization (FAO) of the United Nations, Addis Ababa, Ethiopia
}

Email address:

kipta2012@gmail.com (R. K. Leitich)

${ }^{*}$ Corresponding author

\section{To cite this article:}

Robert Kiptabut Leitich, W. Arinaitwe, B. Mukoye, D. O. Omayio, A. K. Osogo, H. K. Were, J. W. Muthomi, R. M. Otsyula, M. M. Abang. Mapping of Angular Leaf Spot Disease Hotspot Areas in Western Kenya Towards Its Management. American Journal of Applied Scientific Research. Vol. 2, No. 6, 2016, pp. 75-81. doi: 10.11648/j.ajasr.20160206.17

Received: October 23, 2016; Accepted: November 18, 2016; Published: December 21, 2016

\begin{abstract}
Common bean (Phaseolus vulgaris L.) is an important crop in the daily diet of more than 300 million people worldwide. Despite its importance, bean productivity is declining in western Kenya due to diseases and use of low yielding susceptible varieties. Among the diseases, ALS is a major biotic constraint of bean production in western Kenya. It causes an estimated yield loss of about $80 \%$ in the farmers' field when severe. There is still limited information on pathogen distribution in western Kenya hindering breeding for ALS resistance. Therefore, a study was conducted to determine the occurrence of ALS disease in bean growing areas of western Kenya. A disease survey was carried out during the long and short rains seasons of 2013 in six agro-ecological zones namely: Low midland zone 1 (LM1) (Rongo and Bumula), low midland zone 2 (LM2) (Busia, Bungoma and Rangwe), low midland zone 3 (LM3) (Siaya and Teso north), low midland zone 4 (LM4) (Bondo), lower highlands (LH1) (Nandi Central) and upper midland zone 1 (UM1) (Sabatia and Nandi south). UM1 recorded the highest disease incidence and severity, whereas LM4 registered the least. Similarly, there was a significant positive correlation between disease incidence and severity $(r=0.711 ; \mathrm{p}<0.0001)$. The study found the incidence and severity levels of ALS in western Kenya as high as $100 \%$ and 3 respectively. Therefore, farmers should be encouraged to use certified seeds to minimise the severity of the disease.
\end{abstract}

Keywords: Beans, Incidence, Phaeoisariopsis griseola, Severity, Survey

\section{Introduction}

Common bean is the most widely grown pulse, second only to maize as a food crop and a major source of food security in East Africa [1]. In Kenya, the crop is ranked the second most important staple diet after maize [2]. Per capita consumption of beans varies from country to country and region to region, within a country. However, there is often a higher consumption of bean among low income families both in rural and urban areas [3]. In Kenya, per capita consumption is estimated at $14 \mathrm{~kg}$ per year, but can be as high as $66 \mathrm{~kg}$ per year in western Kenya [4], [5].

Bean yields Kenya have remained low on-farm with an average yield of $585 \mathrm{~kg} / \mathrm{ha}$ compared to Ethiopia and Rwanda with yields of $1588 \mathrm{~kg} / \mathrm{ha}$ and $913 \mathrm{~kg} / \mathrm{ha}$ respectively [6]. Empirical evidence shows that poverty levels would have been 0.4 and $0.1 \%$ higher in Rwanda and Uganda, respectively, in the absence of the development and adoption of improved bean varieties. With regard to food 
security, it was found that, in the absence of bean varietal improvement, food security would have been substantially lower in both countries [7]. The low bean yield in the region is attributed to a number of factors, among them diseases and use of low yielding disease susceptible varieties [8], [9]. Among the diseases, ALS caused by (Phaeoisariopsis griseola) is a major biotic constraint of bean production in western Kenya. When weather conditions are favourable for its development, ALS can be very destructive with crop losses resulting mainly from premature defoliation [10]. In addition to seed, water and air currents play an important role in dissemination of P. griseola [11]. As much as $50 \%$ to $80 \%$ reductions in yields of some popular commercial bean varieties due to ALS have been reported in some countries [12], [13].

A survey conducted to determine prevalence, incidence and severity of angular leaf spot revealed that the disease is widely distributed in Kenya. The disease was prevalent in all the five districts surveyed i.e. Kakamega, Kiambu, Embu, Machakos and Taita Taveta and disease incidence, and severity were generally high [14]. However, the case in western Kenya is not known. In addition, there is limited information on pathogen distribution in western Kenya hindering breeding for ALS resistance. Thus, a disease survey was necessary for mapping of ALS hotspots areas and non-hotspots areas in the region as the process of designing an effective ALS breeding program requires precise and accurate knowledge on spatial and temporal distribution of ALS [13].

\section{Materials and Methods}

\subsection{Study Areas}

The study was carried out during the long rains (March to June) and short rains season (October to December) of 2013 in six agro ecological zones (AEZs) [15] namely: Low midland zone 1 (LM1), Rongo and Bumula, low midland zone 2 (LM2), Busia, Bungoma and Rangwe, low midland zone 3 (LM3), Siaya and Teso North, low midland zone 4 (LM4), Bondo, lower highlands (LH1), Nandi Central and upper midland zone 1 (UM1), Sabatia and Nandi south (Table 1) where beans are popularly grown in western Kenya. A total of 334 households were covered in the study. The number of households per AEZs was based on population sampling as described by [16].

Table 1. Characteristics of the AEZs covered and the number of households surveyed.

\begin{tabular}{|c|c|c|c|c|}
\hline AEZs & Altitude (m) & Rainfall (mm) & Average temp. $\left({ }^{\circ} \mathrm{C}\right)$ & Number of farms sampled \\
\hline LH1 & $1950-2400$ & $1600-2000$ & $15.2-18.0$ & 63 \\
\hline UM1 & $1500-2000$ & $1540-1800$ & $18.0-21.0$ & 62 \\
\hline LM1 & $1350-1550$ & $1600-1800$ & $21.1-22.0$ & 60 \\
\hline LM2 & $1350-1500$ & $1350-1650$ & $20.9-22.0$ & 61 \\
\hline LM3 & $1200-1400$ & $1200-1450$ & $21.6-22.4$ & 64 \\
\hline LM4 & $1135-1200$ & $600-1100$ & $22.3-22.7$ & 24 \\
\hline Total & & & & 334 \\
\hline
\end{tabular}

AEZs - agro-ecological zone; LM1 - lower midland zone 1; LM2 - lower midland zone 2; LM3 - lower midland zone 3; LM4 - lower midland zone 4; UM1 - upper midland zone 1; LH1 - lower highland zone 1. Source: [15]

\subsection{Sampling Procedure}

Both purposive and simple random sampling methods were used to select the bean farms and sampling sites. Sampling was done during the long rains season (March to June) and short rains season (October to December) of 2013. The sampling sites within AEZs were bean fields both in pure stand and intercropped. Sampling points within a bean field were randomly selected and disease incidence was determined in each sampling point at an area of $10 \mathrm{~m}^{2}$. Disease incidence was determined as the number bean plants infected (showing ALS symptoms) over the total number of bean plants within the $10 \mathrm{~m}^{2}$ area multiplied by 100 .

$$
\text { Disease incidence }=\frac{\text { No.of plants infected }}{\text { Total number of plants observed }} \times 100
$$

Scoring was based on a rating scale of [17] where: low incidence $=1-20 \% ;$ moderate incidence $=21-49 \%$ and high incidence $=50-100 \%$. While disease severity was estimated as the proportion of the infected plant area by ALS disease within an area of $10 \mathrm{~m}^{2}$. It was assessed on a $0-3$ scale where $0=$ No disease; $1=$ Mild; $2=$ Moderate and $3=$ Severe. The same procedure was repeated for three more sampling points within the field.

\subsection{Determination of ALS Incidence of Bean Varieties Grown by Farmers Sampled}

A survey disease score sheet was used to determine the incidence of ALS on beans grown on the farms surveyed. Growing bean varieties were examined and scored for incidence by counting the number bean plants infected (showing ALS symptoms) over the total number of bean plants within the $10 \mathrm{~m}^{2}$ area multiplied by 100 as already described above. The percentages so obtained were recorded and used to determine the incidences on different bean varieties.

\subsection{Determination of Bean Varieties Grown by the Farmers and Source of Seed}

A score sheet was used record the bean varieties grown on individual farmer's fields and source of seed used by the farmers for planting. The farmers sampled were all able to identify the varieties there were growing by showing the remnants of seed samples. The samples were collected and taken to KALROKakamega for confirmation by the bean breeder. 


\subsection{Statistical Analysis}

Data was subjected to analysis of variance using SPSS version 22, at $(\mathrm{P}<0.05)$ and means separated using least significant difference (LSD) at $5 \%$ probability level. Correlation between occurrence and severity means was also done.

\section{Results}

\subsection{Occurrence and Severity of ALS in Bean Growing Areas of Western Kenya}

The survey results of occurrence as depicted by the

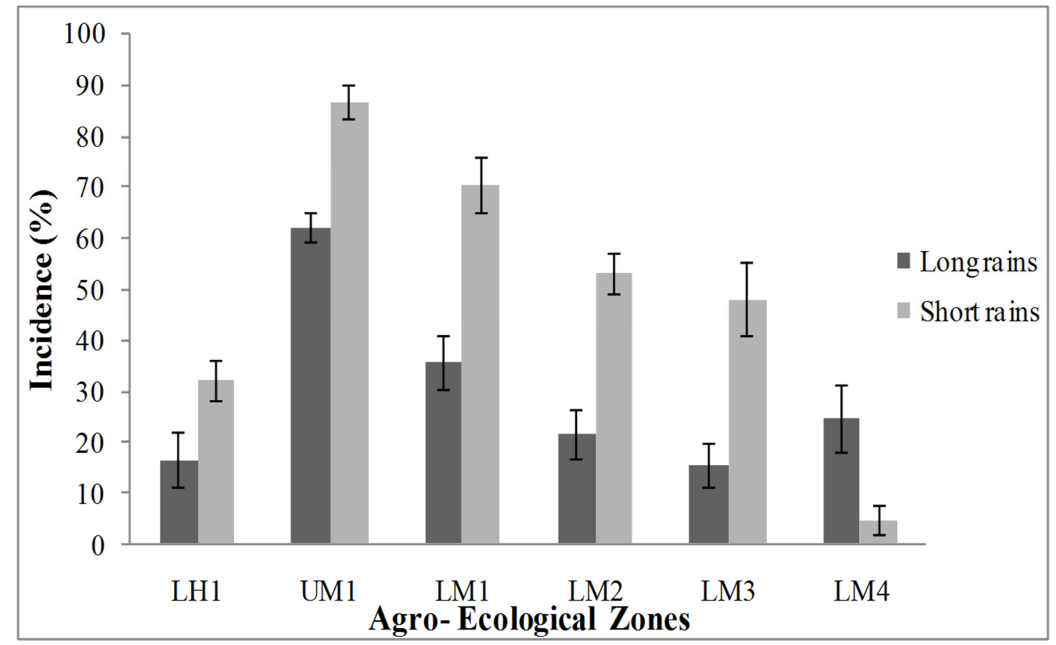

Figure 1. Incidence of ALS across AEZs surveyed.

AEZ - agro-ecological zone; LM1 - lower midland zone 1; LM2 - lower midland zone 2; LM3 - lower midland zone 3; LM4 - lower midland zone 4; UM1 upper midland zone 1; LH1 - lower highland zone 1

Likewise, the severity of ALS across the AEZs ranging from high altitude (LH1) to lower altitude (LM4) was similarly distributed as for the occurrence in the two bean growing seasons (Fig. 2). The highest disease severity was reported in medium altitude (UM1, LM1, LM2 and LM3) whereas high altitude areas and lower altitude areas had the incidence and severity of ALS in bean growing areas of western Kenya are presented in Fig. 1 below. ALS disease of beans was reported to occur in all AEZs surveyed in both long and short rain seasons. The incidence of ALS across the AEZs ranging from high altitude (LH1) to lower altitude (LM4) followed a normal distribution in the two bean growing seasons. The highest diseases incidences were reported in medium altitude (UM1, LM1, LM2 and LM3) in both seasons. Generally, there was high disease incidence in short rains compared to long rains.

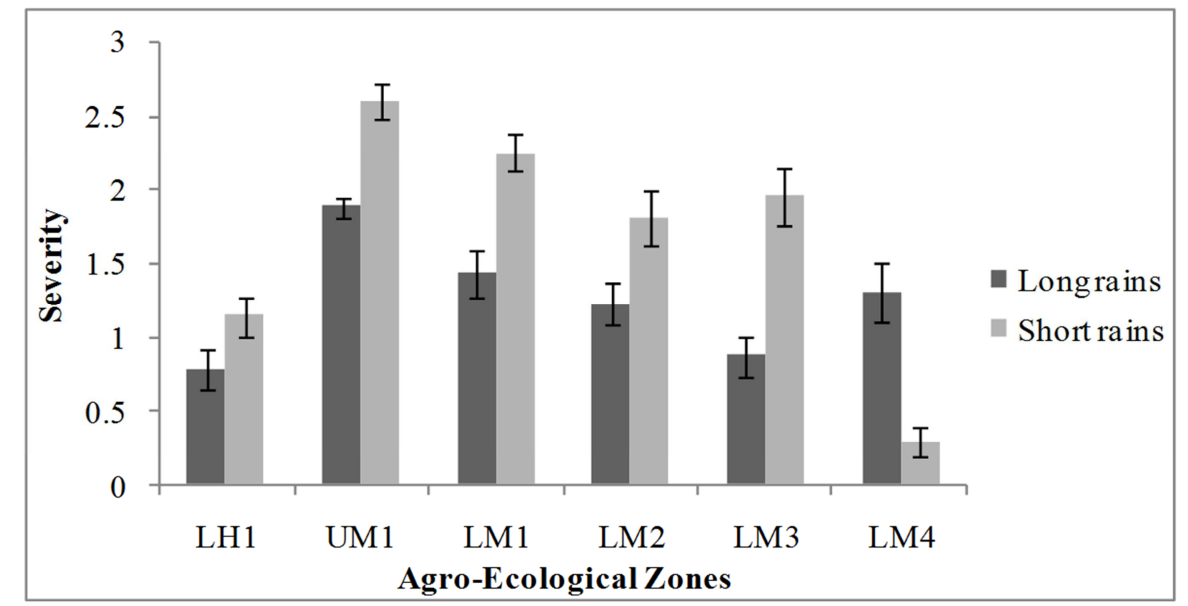

Figure 2. Variation of disease severity across AEZs.

AEZ - agro-ecological zone; LM1 - lower midland zone 1; LM2 - lower midland zone 2; LM3 - lower midland zone 3; LM4 - lower midland zone 4; UM1 upper midland zone 1; LH1 - lower highland zone 1

lowest disease severity in both seasons. Therefore, there was a significant strong positive correlation between disease severity and incidence $(\mathrm{r}=0.711 ; \mathrm{df}=5 ; \mathrm{p}<0.000)$. The high disease severity in the two seasons was observed to be accompanied with heavy leaf defoliation before reaching physiological maturity.

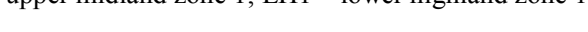


The incidence and severity data from the AEZs discussed above were also plotted on a map as disease index as shown in Fig. 3 below, where 4.1-6.0 = high disease index, 2.1-4.0= moderate disease index and 0.0-2.00=low disease index.

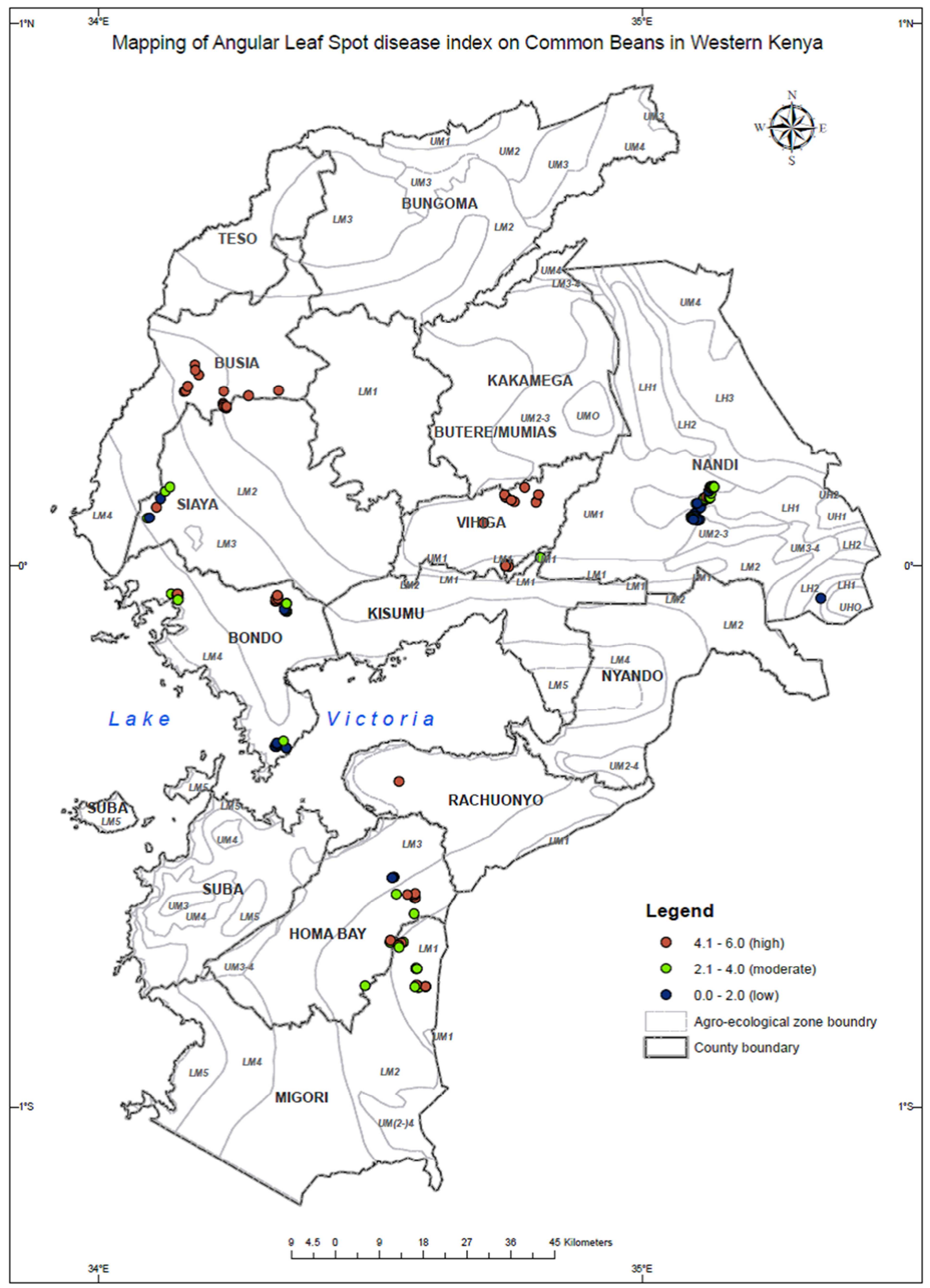

Figure 3. Map of western Kenya showing occurrence of ALS in different AEZs surveyed. 


\subsection{Incidence of Angular Leaf Spot on Bean Varieties Grown by Farmers}

Table 2. Angular leaf spot incidence among the varieties.

\begin{tabular}{lll}
\hline & Disease mean & \\
\hline Variety & Season $\mathbf{1}^{*}$ & Season 2* \\
\hline KK15 & 57.00 & 95.00 \\
KK8 & 54.84 & 28.83 \\
KATX56 & 39.56 & 69.00 \\
Zaire & 34.93 & 60.77 \\
Punda & 52.00 & 60.86 \\
GLP-585 & 32.38 & 45.00 \\
GLP-2 & 24.74 & 42.93 \\
\hline
\end{tabular}

Disease mean $(\%), 1^{*}=$ Long rain season, $2^{*}=$ Short rain season

\subsection{Bean Varieties Grown by the Farmers and Source of Seed}

From the survey results, ALS was found infecting all the bean varieties sampled on the farmer's fields. Generally during the long rains season, KK15 and Punda registered the high incidence, while GLP-2 registered the least incidence across all the AEZs studied. In the short rains season, however, KK15, KATX56 and Punda registered the highest disease incidence, while KK8 registered the least incidence (Table 2). There were no notable trends and differences between the varieties across AEZs

The results of grown bean varieties in the AEZs studied are reported in Table 3. Bean variety GLP 2 (large seeded rosecoco type) was found growing in all AEZs sampled. GLP 585 (small seeded red variety referred to as Wairimu) was found growing in all medium and high altitude zones but missing in low altitude zones of LM3 and LM4. The newly released varieties KK15 and KK8 were found growing in high and medium zones but totally missing in lower altitudes of LM3 and LM4. The dryland variety KATX56 (released by Katumani bean breeding program) was found growing in LM2 but missing in other zones. The local varieties, Punda and Zaire were grown in LM1, LM2 and LM3 but missing in other zones (Table 3 ).

Table 3. Bean varieties preferred across different AEZs.

\begin{tabular}{|c|c|c|c|c|c|c|c|c|c|c|c|c|}
\hline \multicolumn{13}{|l|}{ AEZs } \\
\hline \multirow{2}{*}{ Variety } & \multicolumn{2}{|l|}{ LH1 } & \multicolumn{2}{|l|}{ UM1 } & \multicolumn{2}{|l|}{ LM1 } & \multicolumn{2}{|l|}{ LM2 } & \multicolumn{2}{|l|}{ LM3 } & \multicolumn{2}{|l|}{ LM4 } \\
\hline & $1 *$ & $2 *$ & $1 *$ & $2 *$ & $1 *$ & $2 *$ & 1* & $2 *$ & $1 *$ & $2 *$ & $1 *$ & $2 *$ \\
\hline GLP-585 & 16.7 & 3.5 & 23.3 & 33.3 & 0.0 & 10.7 & 29.6 & 17.7 & 21.4 & 0.0 & 0.0 & 18.2 \\
\hline KK8 & 2.1 & 31.9 & 30.2 & 16.7 & 10.7 & 0.0 & 2.3 & 0.0 & 0.0 & 7.7 & 0.0 & 0.0 \\
\hline KK15 & 0.0 & 0.0 & 15.1 & 33.3 & 3.6 & 0.0 & 2.3 & 0.0 & 0.0 & 0.0 & 0.0 & 0.0 \\
\hline KATX 56 & 0.0 & 0.0 & 0.0 & 0.0 & 3.6 & 17.9 & 15.9 & 17.7 & 0.0 & 0.0 & 8.3 & 0.0 \\
\hline Punda & 14.6 & 0.0 & 7.0 & 0.0 & 3.6 & 7.1 & 6.8 & 29.4 & 0.0 & 0.0 & 0.0 & 0.0 \\
\hline Zaire & 0.0 & 0.0 & 0.0 & 0.0 & 28.6 & 21.4 & 4.6 & 5.9 & 17.9 & 38.5 & 0.0 & 9.1 \\
\hline
\end{tabular}

$1^{*}=$ Long rain season, $2 *=$ Short rain season. AEZ - agro-ecological zone; LM1 - lower midland zone 1; LM2 - lower midland zone 2; LM3 - lower midland zone 3; LM4 - lower midland zone 4; UM1 - upper midland zone 1; LH1 - lower highland zone 1

\subsection{Sources of Bean Seed for Planting}

Most farmers obtained their seeds from local markets $(48.3 \%)$ and own seed sourced or recycled (39.7\%); whereas the agro dealer and neighbour sources were the least sources of seed (below 5\%) (Fig. 4).

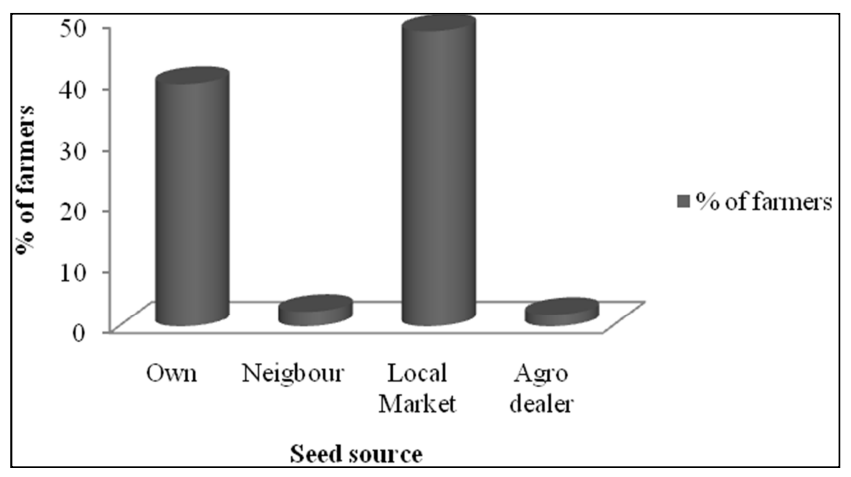

Figure 4. Bar chart showing proportion of farmers and their seed sources.

\section{Discussion}

The high incidence and severity of ALS disease of beans reported in medium altitude zone of the surveyed areas is attributed to moderate temperature range $\left(20-25^{\circ} \mathrm{C}\right)$ and high relative humidity $(70-100 \%)$ that provides favourable conditions for the successful infection of the host and sporulation of the pathogen, a characteristic of medium altitude areas ranges of 1500-1700 m.a.s.1 [13]. This is in line with the findings of [18] who reported high ALS disease incidence and severity in Kakamega (UM1) and parts of eastern (LM3) of Kenya. While the low incidence and severity in LH1 could be due to low average temperatures (below $20^{\circ} \mathrm{C}$ ) associated with such altitudes which as a results delays disease development [19]. In lower midlands (LM3 and LM4) however, the disease incidences that were low could be attributed to high temperatures (above $25^{\circ} \mathrm{C}$ ), low rainfall and low humidity which are unfavourable for successful infection of the host and sporulation of the pathogen. This finding concurs with [20] who also observed 
a systematic disease decrease as temperature increases.

The high disease incidence and severity in short rains season as compared to long rains season could be attributed to the farming practices adopted by the farmers in the region. Beans are a major food crop and small-scale farmers are reluctant to decrease the frequency of sowing beans on a small piece of land [9]. This makes it difficult to culturally control ALS by season differentiation. The gap between the long rains cropping season and the short rain season is short and sometimes results in relay growing that encourages a build up of ALS through recycling of bean plant debris that becomes a major source of inoculum to ALS. Furthermore, [21] reported that ALS increased dramatically in Colombia when four bean crops were planted per year in Cauca valley. Even when planted twice yearly, the disease was especially serious where beans were planted in or near fields cultivated with beans during the previous one or more seasons [21].

There was no clear trend on the incidence and severity of ALS noted on beans varieties grown by the farmers in the study since none of the varieties grown by the farmers was bred for ALS resistance [22]. A large number of varieties were grown by the farmers and the large seeded rocecoco types were predominant on the farmers' fields. The farmers did not however link this to the ALS tolerance. The earlier released bean varieties GLP 2 and GLP 585 seemed predominant across the AEZs. This is due to the fact that these varieties have been in commercial production for over 2 decades [22]. Varieties KK8 and KK15 that were predominant in medium altitude are recently released varieties that were tested extensively in medium altitude by KALRO Kakamega in recent years [23]. Variety KATX56 that was reported in lower midland (LM1 and LM 2) is a dryland variety developed and tested by KALRO Katumani in this region [23]. It was also noted in the study that the local cultivars Punda and Zaire were predominantly grown in lower midland (LM2 and LM3). This could be attributed to the fact that the breeding program of KALRO Kakamega has developed very few varieties for this region which previously was under dryland breeding program.

Since almost all the seed planted by the farmers was from open market and recycled farmers own seed, explains high disease incidence and severity reported in the study across the AEZs and seasons. Infected seed has been reported as one of the main sources of infection that often results in inoculum build up that causes severe disease occurrences [21].

\section{Conclusion}

In conclusion, it was found out that, there is high incidence and severity of ALS disease of common beans in medium altitude zones of the areas surveyed. High disease incidence and severity was noted in short rains season as compared to long rains season. In addition, it was noted a large number of varieties grown by the farmers were the large seeded rocecoco types and the seeds planted by the farmers were from open market and recycled farmers own seed.

Based upon the findings and conclusions of this study, it is recommended that the areas with low disease incidence and severity (LM4) should be used for bean seed production. Moreover, the farmers should be encouraged to use certified seeds to minimise the severity of the disease.

\section{Abbreviations}

\author{
AEZs - Agro-ecological Zones \\ ALS - Angular Leaf Spot \\ FAOSTAT - Food and Agricultural Organization Statistics \\ CIAT-International Centre for Tropical Agriculture \\ GPS - Global Positioning System \\ LH - Lower Highlands \\ LM - Lower Midlands \\ LR - Long rain \\ MOA - Ministry of Agriculture \\ SR- Short rain \\ UM - Upper Midlands
}

\section{Acknowledgement}

The author (s) would like to thank the National Commission for Science and Technology and Innovation (NACOSTI/RCD/ST\&I, $5^{\text {th }}$ CALL M.Sc/016) and CIAT for financial support during the study. Above all, the Almighty God for the gift of life.

\section{References}

[1] Mauyo, LW, Okalebo, JR, Kirby, RA, Buruchara, RM, Ugen, MA and Musebe, RO. 2007. Legal and institutional constraints to Kenya-Uganda cross-border bean marketing. African Journal of Agricultural Research 2: 578-582.

[2] Muasya, RM. 2001. Crop physiological analysis of seed quality variation in common Beans (Phaseolus vulgaris L.)," Ph.D. Thesis, Wageningen University, the Netherlands.

[3] Hillocks RJ, Madata, CS, Chirwa R, Minja, EM and Msolla S. 2006. Phaseolus bean improvement in Tanzania 1959-2005. Euphyta. 150: 225-231.

[4] Spilsbury J, Jagwe, J and Wanda, K. 2004. Evaluating the Marketing Opportunities for beans and its products in the principle beans growing countries of ASARECA, draft regional report compiled by International Institute of Tropical Agriculture and Food net.

[5] Buruchara R, Chirwa, R, Sperling, L, Mukankus, IC, Rubyogo, JC, Muthoni, R and Abang, MM. 2011. Development and delivery of bean varieties in africa: The panAfrica bean research alliance (PABRA) model. African Crop Science Journal, Vol. 19, No. 4, pp. 227-245.

[6] FAOSTAT, 2014. Food and agriculture organization at http://faostat.fao.org

[7] Larochelle, C, J Alwang, GW, Norton, E. Katungi, and RA. Labarta. 2013. Ex-post impact of adopting improved bean varieties on poverty and food security in Uganda and Rwanda. In: Diffusion and impact of improved varieties in Africa (DIIVA) - Objective 3 Report. Virginia Tech; CIAT, Blacksburg, VA; Cali, Colombia. 
[8] Nderitu J N and Otsyula, RM. 1997. Survey of bean root rots, bean stem maggot, soil fertility and management practices in farmer's fields. Annual report RRC Kakamega. 32pp.

[9] Otsyula RM, Ajanga, SI, Buruchara, RA. and Wortman, CS. 1998. Developments of an integrated bean root rot control strategy for western Kenya. African Crop Science Journal 6: 61-67.

[10] Mwang'ombe, A. W, Kamani, P. M. and Kimenju, J. W. (1994). Evaluation of advanced bean lines for resistance to 6 major diseases in Kenya. A Paper presented during the workshop for bean research collaborators.

[11] Liebenberg MM and Pretorius, ZA. 1997. A review of angular leaf spot of common bean (Phaseolus vulgaris L.). African Plant Protection 3: 81-106.

[12] Opio F, Ugen, MA, Kyamanywa, S, David, S and MugisaMutetikka, M. 2001. Beans. In J. K. Mukiibi (Ed.), Agriculture in Uganda: Crops II (pp. 162-191). Kampala, Uganda: Fountain Publishers.

[13] Stenglein SA, Ploper, D, Vizgarra, O and Balatti, P. 2003. Angular leaf spot: A disease caused by the fungus Phaeoisariopsis griseola (Sacc.) Ferraris on Phaseolus vulgaris L. Adv. Applied Microbiol., 52: 209-243.

[14] Wagara, I. N., Mwang'ombe, A. W., Kimenju, J. W. and Buruchara, R. A. 2005. Virulence, variability and physiological races of the angular leaf spot pathogen. Phaeoisariopsis griseola in Kenya. African Plant Protection 11: 23-31.

[15] Jaetzold R., Helmut S., Berthold H. and Chris, S. (2006). Farm management handbook of Kenya, part B. Ministry of Agriculture, Nairobi, Kenya.
[16] Mugenda, O. M. and Mugenda, A. G. (2003). Research Methods: Quantitative and Qualitative Approaches. Nairobi: ACTS Press.

[17] Nono-Womdim, R., Swai I. S., Green S. K., Gebre-Selassie K., Latterot H., Marchoux G., and Opena R. T. (1996). Tomato viruses in Tanzania: Identification, distribution and disease incidence. Journal of South African Society of Horticulture 6: $41-44$.

[18] Mwang'ombe AW, Wagara, IN, Kimenju, JW and Buruchara, RA. 2007. Occurrence and severity of the angular leaf spot of common bean in Kenya as influenced by geographical location, altitude and agro-ecological zones. Plant Pathology Journal, 6: 235-241.

[19] Inglis DA and Hagedorn DJ. 1986. Temperature requirements by Isariopsis griseola for infection and disease development on red kidney beans. Ann. Rep. Bean Improv. Cooperative, 29: 35-35.

[20] Verma BR and Sharma, SL. 1984. Variability in Phaeoisariopsis griseola the causal agent of angular leaf spot of beans. Indian Phytopathol. 37: 580-581.

[21] Barros OR, Cardona, OC, Cardenosa, R, and Skiles, RL. 1958. The control of angular leaf spot in Colombia. FAO Plant Protect. Bull., 6: 97-101.

[22] Otsyula, R. M. (2010). Nature of genetic control and inheritance of resistance to pythium root rot in bean genotypes. http://research.or.ke/term/23517.

[23] KARI, (2006). Annual Report. KARI Nairobi, Kenya. 